Review

\title{
Coronary Artery Spasm: Review and Update
}

\author{
Ming-Jui Hung1, Patrick Hu2,3, Ming-Yow Hung4,5,6凶 \\ 1. Department of Cardiology, Chang Gung Memorial Hospital, Keelung, Chang Gung University College of Medicine, Taoyuan, Taiwan; \\ 2. International Cardiovascular Institute, Las Vegas, Nevada, USA; \\ 3. Department of Cardiology, Riverside Medical Clinic, Riverside, California, USA; \\ 4. Department of Internal Medicine, School of Medicine, College of Medicine, Taipei Medical University, Taipei, Taiwan; \\ 5. Division of Cardiology, Department of Internal Medicine, Shuang Ho Hospital, Taipei Medical University, New Taipei City, Taiwan; \\ 6. Graduate Institute of Clinical Medical Sciences, Chang Gung University College of Medicine, Taoyuan, Taiwan.
}

$\triangle$ Corresponding author: Ming-Yow Hung, Division of Cardiology, Department of Internal Medicine, Shuang Ho Hospital, Taipei Medical University, New Taipei City, No.291, Zhongzheng Rd., Zhonghe District, New Taipei City, 23561, Taiwan. Tel: +886-2-22490088 ext 2714; Fax: +886-2-82733736; e-mail: myhung6@ms77.hinet.net.

(C) Ivyspring International Publisher. This is an open-access article distributed under the terms of the Creative Commons License (http:/ / creativecommons.org/ licenses/by-nc-nd/3.0/). Reproduction is permitted for personal, noncommercial use, provided that the article is in whole, unmodified, and properly cited.

Received: 2014.05.II; Accepted: 2014.07.3I; Published: 20I4.08.28

\begin{abstract}
Coronary artery spasm (CAS), an intense vasoconstriction of coronary arteries that causes total or subtotal vessel occlusion, plays an important role in myocardial ischemic syndromes including stable and unstable angina, acute myocardial infarction, and sudden cardiac death. Coronary angiography and provocative testing usually is required to establish a definitive diagnosis. While the mechanisms underlying the development of CAS are still poorly understood, CAS appears to be a multifactorial disease but is not associated with the traditional risk factors for coronary artery disease. The diagnosis of CAS has important therapeutic implications, as calcium antagonists, not $\beta$-blockers, are the cornerstone of medical treatment. The prognosis is generally considered benign; however, recurrent episodes of angina are frequently observed. We provide a review of the literature and summarize the current state of knowledge regarding the pathogenesis of CAS.
\end{abstract}

Key words: coronary artery spasm, Prinzmetal's angina, provocative testing.

\section{Introduction}

Myocardial ischemia is not necessarily preceded by increased oxygen demand [1]. In 1959, remarks on "A variant form of angina pectoris" by Dr. Myron Prinzmetal (1908-1987) appeared as the first article [2] distinguishing it as a separate entity from the classic Heberden's angina described in 1772 [3,4], a distinct syndrome with pain provoked with increased cardiac work and relieved by rest or the administration of nitroglycerin. In Prinzmetal's original report of 32 cases of variant angina, the pain associated with transient ST-segment elevation came on with the subject at rest or during ordinary activity but was not brought on by exercise. Of the 32 patients studied, 12 went on to develop myocardial infarction [2]. Since postmortem examination confirmed that coronary atherosclerosis was common to both forms of angina pectoris, spontaneous vascular hypertonus, or coronary artery spasm (CAS) was proposed as the cause of variant angina.

\section{The emergence of coronary artery spasm}

Prinzmetal et al. [2] did an experimental intermittent occlusion of a large epicardial coronary artery in 25 dogs and successfully reproduced the clinical symptoms (e.g. pain) and electrocardiographic presentations of various angina, including various arrhythmias and ST-segment elevation in the corresponding leads. Moreover, the area of ischemia demonstrated systolic ballooning. These changes disappeared when the tie was loosened and could be reproduced repeatedly by tightening or loosening the ligature, suggesting that hypertonus of a diseased vessel is probably the cause of this syndrome. More than a decade later after the introduction of coronary angiography by Sones and Shirey in 1959 [5], several 
reports demonstrated angiographically that CAS was indeed associated with variant angina [6-8].

With the advent of coronary angiography, it became clear that CAS could occur in normal coronary arteries, and was, therefore, referred to as "variant of the variant" [7] or "coronary vasospastic angina" [9]. Recently, many investigators found that most cases of CAS were associated with ST-segment depression rather than ST-segment elevation $[10,11]$. Thus, the term "variant angina" is usually reserved for angina with transient ST-segment elevation.

\section{Epidemiology}

Epidemiologic data show wide differences in the prevalence of CAS in different countries. For example, the frequency of CAS appears to be greater in the Japanese population than that in western populations [12] and the diagnosis of variant angina among patients with angina referred to Japanese medical institutions is made in a high percentage, $40 \%$ [9]. In addition, the frequencies of multiple spasms ( $\geq 2$ spastic coronary arteries) by provocative testing in Japanese (24.3\%) [13] and Taiwanese populations (19.3\%) [14] are markedly higher than those in Caucasians (7.5\%) [15]. In East Asia as well as Western countries, CAS is more prevalent among men than women $[9,14]$. Most patients with CAS are between 40 and 70 years of age, and the prevalence tends to decrease after the age of 70 years $[9,14]$. Previous Asian studies of patients without obstructive coronary artery disease have shown that the prevalence of CAS is around $50 \%$ in patients with angina and $57 \%$ in patients with acute coronary syndrome [16,17]. Similar findings were reported in a German study [18]. Of note, the diagnosis of CAS depends on coronary angiography and provocation tests, which vary from laboratory to laboratory. Premedication with spasmolytic drugs such as nitroglycerin or calcium antagonists, avoidance of coronary constrictors, and daily or monthly variation of disease activity may result in failure to diagnose CAS. Therefore, while there is evidence for racial differences in coronary constrictor response [12], the prevalence of CAS in different populations remains to be defined.

\section{Clinical characteristics}

\section{Myocardial ischemic syndrome}

There is great variability of symptoms. If CAS lasts long enough, it can lead to angina and even myocardial infarction [19]. However, brief episodes of CAS that go unnoticed because they do not induce any symptoms can result in silent myocardial ischemia, or cause life-threatening arrhythmias, resulting in sudden death [20-22]. It has been reported that the incidence of silent myocardial ischemia is more than 2 times higher than that of symptomatic ischemia [20]. Therefore, CAS-related ischemic heart diseases comprise a wide spectrum of myocardial ischemic syndromes, including silent myocardial ischemia, stable angina, unstable angina, acute myocardial infarction and sudden death $[19,20,22,23]$.

CAS occurs most often at rest, particularly from midnight to early morning $[2,19,20,22-26]$. A previous report using intravenous methergine provocation tests showed that the frequency of CAS was 38\% when angina occurred only at rest, compared with $13.8 \%$ when angina at rest was associated with effort angina [15]. Nonetheless, CAS can also be induced by exercise, especially in the morning in some patients [21], and can be associated with ST-segment depression in some patients presenting with stable effort angina [10], suggesting that spastic arteries are abnormal as normal coronary arteries dilate in response to exercise.

There are daily circadian variations in the incidence of CAS [27]. While the causes of circadian variation of CAS remain to be elucidated, the complexity of the local neural events that modulate the tone of the coronary arteries [28], and the association of the occurrence of CAS in the early morning with rapid eye movement [29], during which time there is a rapid elevation of sympathetic activity, suggest that changes in the activity of the autonomic nervous system may be involved in the circadian variation of CAS. Yasue at al. [26] compared the coronary arteriograms quantitatively by measuring the diameter of the major coronary artery in patients with variant angina and found that in the early morning, the tone of the major coronary artery was increased and its diameter was smaller than normal. In contrast, in the afternoon, the major coronary artery was usually dilated. This may be one of the reasons that there is a circadian variation in the exercise capacity of most patients with variant angina.

\section{Electrocardiographic changes}

Electrocardiographic measurements may appear normal at the beginning of CAS or when the CAS is mild [27]. Total or subtotal spasm of a major coronary artery results in ST-segment elevation in the leads corresponding to the distribution of that coronary artery. However, CAS may cause ST-segment depression, indicating less severe, subendocardial myocardial ischemia than does ST-segment elevation. Of note, CAS is more frequently associated with ST-segment depression (Figure 1) rather than ST-segment elevation (Figure 2) $[10,11]$. ST-segment depression occurs when CAS of a major artery is less severe, when a major artery receiving collaterals is 
completely occluded, or when a small artery is completely occluded [30]. This situation occurs in many cases of unstable angina/non-ST-elevation myocardial infarction. A previous study has shown that $45 \%$ of patients with angina at rest and ST-segment depression alone had CAS [15]. In addition to ST-segment changes, a delay in the peak and an increase in the height and width of $\mathrm{R}$ wave, a decrease in magnitude of $S$ wave, peak $T$ wave and negative $U$ wave may also appear [27].

While the location of CAS is fixed over time in some patients, CAS may fluctuate from one vessel to another in others [31]. A previous study showed that alternating ST-segment elevation and depression could occur in the same patient or even in the same lead within minutes or hours [23]. Furthermore, it has been demonstrated that there is variability of electrocardiographic changes during repeated provocative testing and recurrent spontaneous attacks [32,33]. Thus, the direction and extent of ST-segment elevation or depression may change over time. Occasionally, pseudonormalization of a previously depressed ST-segment may appear [27].

CAS is associated with various arrhythmias, including sinus bradycardia, sinus arrest with or without junctional escape beats, complete atrioventricular block, paroxysmal atrial fibrillation, ventricular premature complex, ventricular tachycardia, ventricular fibrillation (VF) and asystole [17,27,34-36]. CAS-associated life-threatening arrhythmias often occur in patients with acute coronary syndrome [17]. Furthermore, CAS-related sudden death most frequently results from bradyarrhythmias, rather than from tachyarrhythmias $[37,38]$.

While VF can often be terminated by cardioversion [15], VF rarely terminates spontaneously [39] as CAS-related spontaneous reversion of VF has been reported to do [40]. Spontaneous termination of VF has been documented in a 62-year-old woman following an acute postero-lateral myocardial infarction [41], a 67-year-old woman with a syncopal episode after awakening from sleep [42], and a 21-year-old woman during exertion at night [43], although CAS was not documented in those reports. In a study of VF episodes in patients with implantable cardioverter defibrillators [44], 43\% were asymptomatic and $40 \%$ were nonsustained episodes. If VF is $<10$ seconds in duration then the incidence of syncope or pre-syncope is $25 \%$, compared with $62 \%$ if the arrhythmia is $\geq 10$ seconds. Therefore, CAS should be considered in the differential diagnosis of syncope.

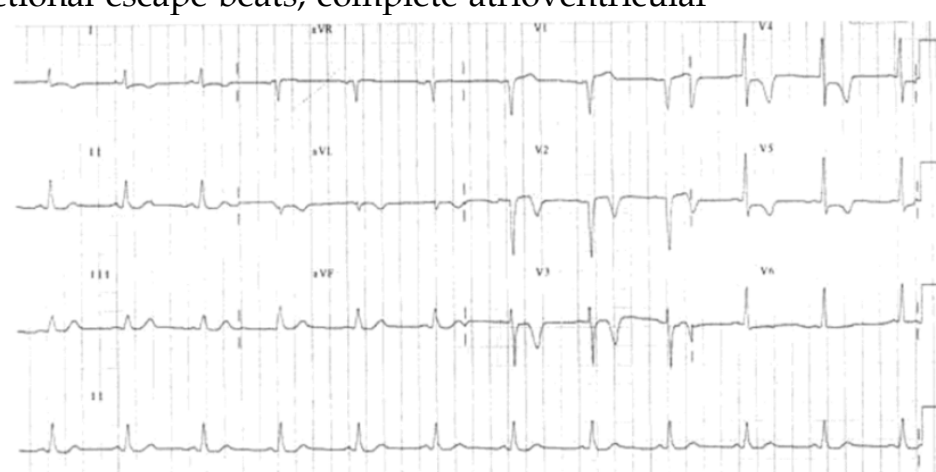

$\mathbf{A}$

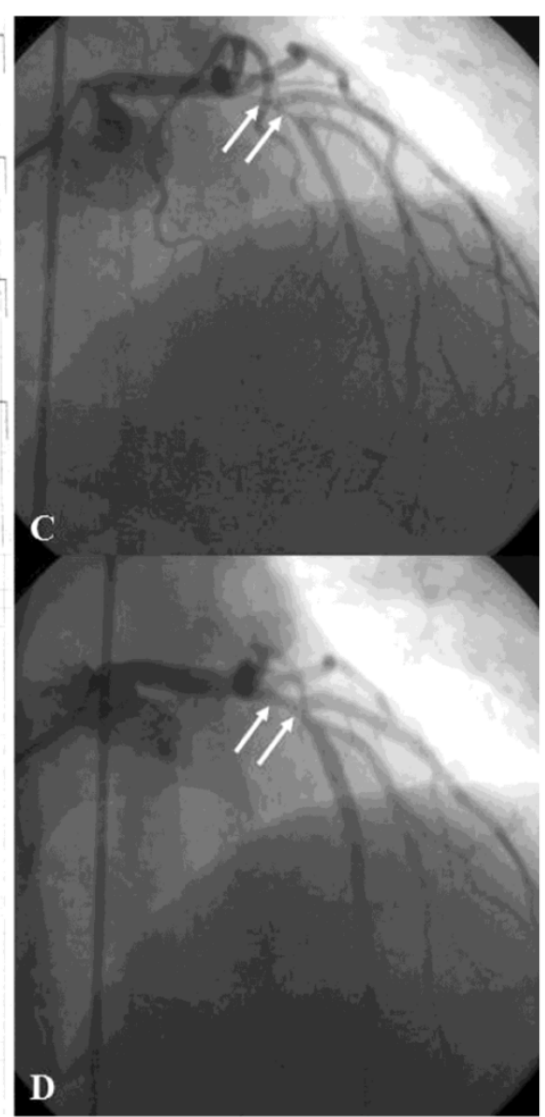

Figure I. (A) Twelve-lead electrocardiogram in a 50-year-old male showing T-wave inversion in leads I, aVL, V2-6. (B) Normal electrocardiogram after 6-month treatment with diltiazem. (C) More than $90 \%$ spontaneous vasospasm in the proximal left anterior descending artery (arrows). (D) The vasospasm was relieved after intracoronary administration of $100-\mu g$ nitroglycerin (arrows). (Reproduced from Hung MY, Hsu KH, Hung MJ, Cheng CW, Kuo LT, Cherng WJ. Interaction between cigarette smoking and high-sensitivity C-reactive protein in the development of coronary vasospasm in patients without hemodynamically significant coronary artery disease. Am J Med Sci. 2009; 338(6): 440-446, with permission of the publisher. Copyright @ Wolters Kluwer Health, 2009.) 


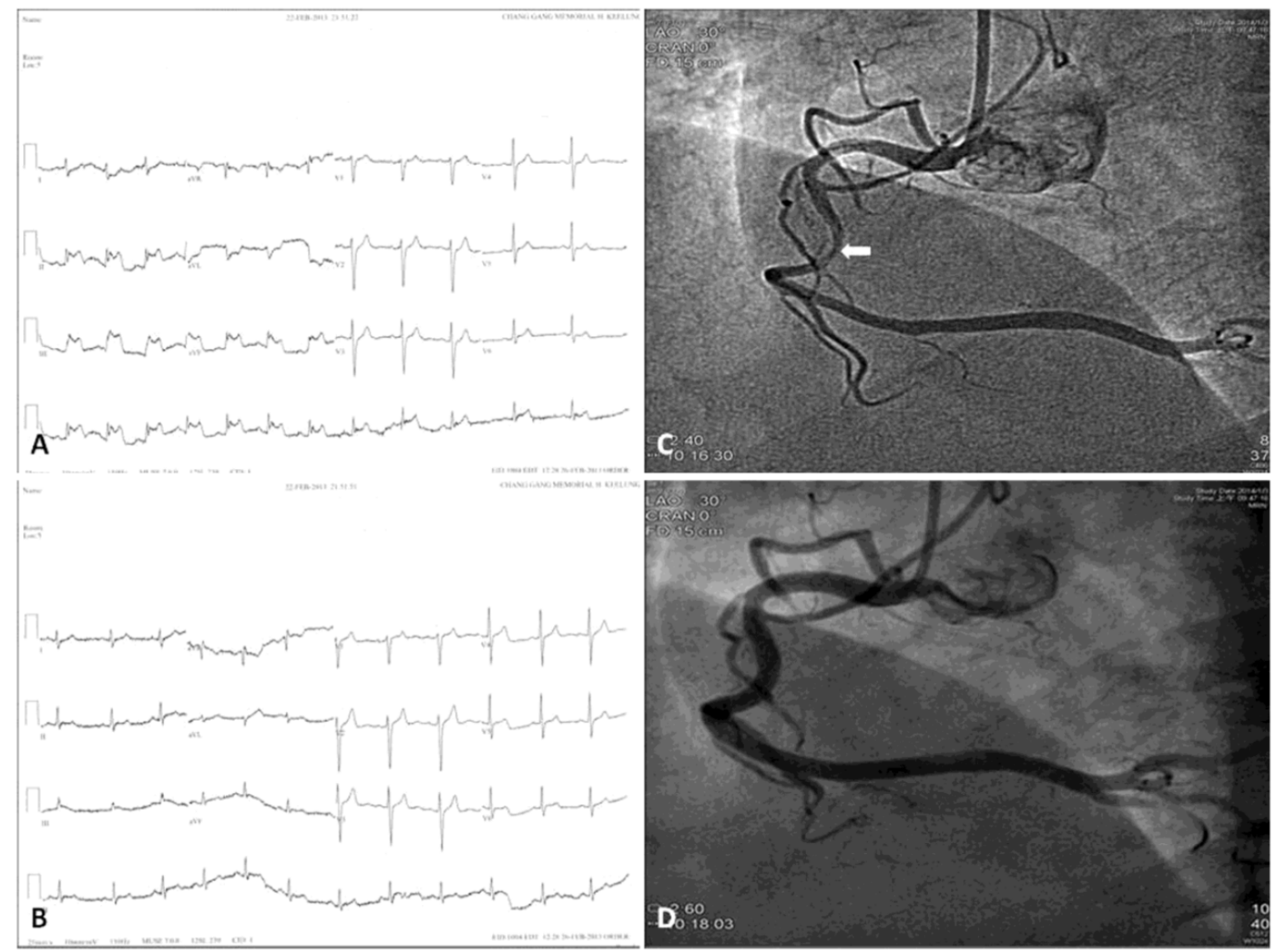

Figure 2. Twelve-lead electrocardiograms and coronary angiograms of variant angina. Chest pain attack (A) and post-sublingual nitroglycerin 0.6 mg (B) Twelve-lead electrocardiograms of a 47-year-old male patient who had variant angina show transient ST-segment elevation in the II, III, and aVF leads. Ten months later he underwent coronary angiography because of recurrent chest pain. The coronary angiograms reveal intracoronary methylergonovine-induced diameter reduction $>70 \%$ in the mid-portion of right coronary artery (C, arrow), which was relieved after intracoronary nitroglycerin $200 \mu \mathrm{g}$ administration (D).

\section{Risk factors and precipitating factors}

\section{Risk factors}

Smoking, age and high-sensitivity C-reactive protein (hs-CRP) are significant risk factors for CAS $[45,46]$. Risk factors often coexist and interact with one another (Figure 3). It has been shown that while the older subjects are more likely to develop CAS than their younger analogs, smoking has a stronger effect on CAS occurrence in the younger than in their older counterparts [47]. Furthermore, those factors may be gender-specific, as smoking and age seem to play a more significant role in men $[14,45]$. While active smokers constitute $45-75 \%$ of patients with CAS, $25-55 \%$ of patients do not smoke $[45,48,49]$. Moreover, despite a similar frequency of cigarette smoking in study populations, a prospective comparative study of CAS between Japanese and Italian patients 7 to 10 days after myocardial infarction observed a marked difference in CAS between these 2 groups, with $80 \%$ of the Japanese and $37 \%$ of the Caucasian patients showing inducible CAS [50]. Therefore, other factors may affect CAS development.
While high hs-CRP level has recently been found to be an important risk factor for CAS, its relationship with CAS may differ between genders [45,51]. In patients with low hs-CRP levels, diabetes mellitus has been shown to contribute to CAS development in men but not in women [45]; however, in patients with high hs-CRP levels, there are negative effects of diabetes mellitus and hypertension on CAS development, especially in women [45]. It has been demonstrated that female gender does not reduce the risk of developing obstructive coronary artery disease in terms of diabetes mellitus and hypertension [52,53], suggesting that the pathogenesis of CAS may differ from that of obstructive coronary artery disease.

\section{Precipitating factors}

Precipitating factors may contribute to the onset of CAS and act in the same patient to cause angina in different conditions (Figure 3). CAS can be precipitated by physical and/or mental stress [54], magnesium deficiency [55], alcohol consumption [56], the cold pressor test, hyperventilation, the Valsalva maneuver, remnant lipoproteins [57], and the administration of pharmacological agents such as cocaine 


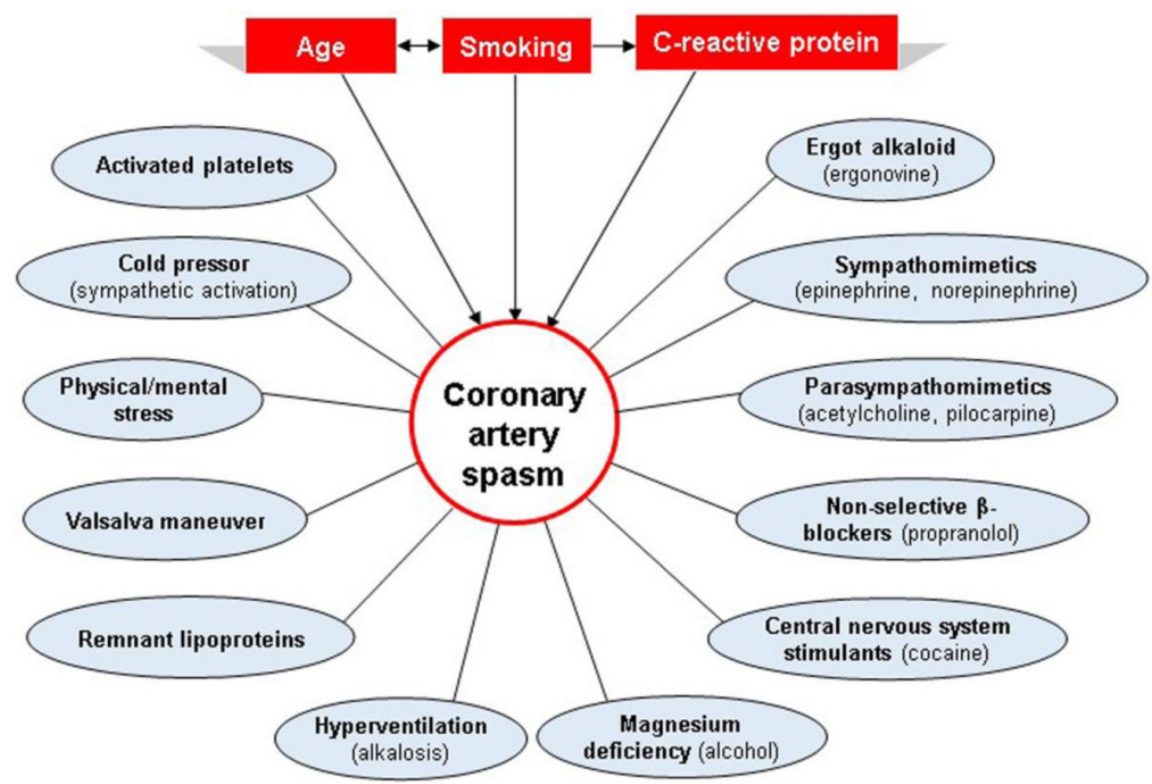

Figure 3. Risk factors and precipitating factors for the development of coronary artery spasm (CAS). While risk factors, which often coexist and interact with one another, increase a person's susceptibility to developing CAS, precipitating factors may contribute to the onset of CAS and act in the same patient to cause angina in different conditions. The risk factors and precipitating factors are represented by rectangles and circles, respectively. serotonin, both of which are found to be associated with CAS [59-61]. It is important to differentiate CAS from Kounis syndrome because there is some overlap between the 2 entities. Kounis syndrome is characterized by the concurrence of acute coronary events with allergic or hypersensitivity reactions [62]. To differentiate Kounis syndrome from CAS, knowledge of individual hypersensitivity is crucial.

\section{Pathogenesis}

The causes and the mechanisms underlying the development of CAS are still poorly defined and are likely multifactorial (Table 1). In the 1980s, the autonomic nervous system was found to play an important role in the pathophysiology of CAS

[58], sympathomimetic agents (epinephrine, norepinephrine, etc.), beta-blocking agents (propranolol, etc.), parasympathomimetic agents (methacholine, pilocarpine, etc.), and ergot alkaloids (ergonovine, ergotamine, etc.), particularly in the morning when spontaneous CAS is most likely to occur [26]. Activated platelets may trigger CAS by releasing vasoconstrictor substances, including thromboxane and
$[27,63,64]$. In the 1990s, inflammation, endothelial dysfunction, oxidative stress, respiratory alkalosis and magnesium deficiency were identified as predisposing factors [27]. In the late 1990s and early 2000s, genetic mutations were found to be associated with CAS [27]. Nonetheless, coronary vascular smooth muscle cell hyperreactivity seems to constitute the substrate for CAS.

Table I. Proposed mechanisms of coronary artery spasm.

\begin{tabular}{|c|c|c|}
\hline Etiology & Mechanism & Comments \\
\hline $\begin{array}{l}\text { Autonomic nervous } \\
\text { system }\end{array}$ & $\begin{array}{l}\text { Frequent attacks at night when vagal tone is high } \\
\text { Directly induced by catecholamines [60] or by stimuli (exercise, cold pressor test, cocaine, } \\
\text { amphetamines) }[70,114] \text {. }\end{array}$ & $\begin{array}{l}\text { Night attacks frequently occur during rapid eye movement } \\
\text { sleep, when a reduction in vagal activity is associated with } \\
\text { an increase in adrenergic activity [26,27]. } \\
\text { Spontaneous attacks are often preceded by a reduction of } \\
\text { vagal activity [66], and followed by an increase in coronary } \\
\text { levels of catecholamines [67]. }\end{array}$ \\
\hline Inflammation & $\begin{array}{l}\text { Elevated peripheral white blood cell and monocyte counts, hs-CRP, interleukin- } 6 \text {, and } \\
\text { adhesion molecules }[16,50] \text {. }\end{array}$ & $\begin{array}{l}\text { Inflammation is prevalent in CAS and atherosclerosis, it, } \\
\text { therefore, may not constitute by itself a major direct cause. }\end{array}$ \\
\hline $\begin{array}{l}\text { Endothelial dysfunc- } \\
\text { tion }\end{array}$ & $\begin{array}{l}\text { Acetylcholine, ergonovine, serotonin, or histamine, all of which are endotheli- } \\
\text { um-dependent vasodilators, cause vasodilation by inducing nitric oxide release from the } \\
\text { normal endothelium. While in the presence of endothelial dysfunction, they can induce } \\
\text { CAS [27]. }\end{array}$ & $\begin{array}{l}\text { Endothelial dysfunction is not always present in CAS } \\
{[86,87] \text {. }}\end{array}$ \\
\hline $\begin{array}{l}\text { Smooth muscle cell } \\
\text { hypercontractility }\end{array}$ & $\begin{array}{l}\text { Rho-kinase activity is enhanced in coronary artery smooth muscle cells by inflammation } \\
\text { in a porcine model [88-90]. } \\
\text { Spontaneous CAS has been developed in } K_{\text {ATP }} \text { mutant or SUR } 2 K_{\text {ATP }} \text { knockout mice } \\
\text { [93,94]. Mice deficient in } \alpha_{1 H} \text { T-type calcium channel have reduced relaxation in response } \\
\text { to acetylcholine [95]. }\end{array}$ & $\begin{array}{l}\text { Their relevance to CAS in humans remains to be eluci- } \\
\text { dated. }\end{array}$ \\
\hline Oxidative stress & $\begin{array}{l}\text { NO could be degraded by oxygen free radicals [96-99]. } \\
\text { Oxygen-reactive species have a detrimental effect on the vessel wall, leading to inflam- } \\
\text { mation, endothelial damage [98] and vascular smooth muscle cell constriction [100]. } \\
\text { In CAS, there are low plasma levels of vitamin E [101] and high plasma levels of thiore- } \\
\text { doxin [102]. }\end{array}$ & $\begin{array}{l}\text { It has been reported that there is no endothelial NO defi- } \\
\text { ciency and dysfunction in patients with CAS [103]. }\end{array}$ \\
\hline Genetics & $\begin{array}{l}\text { Mutation or polymorphism of the endothelial NO synthase gene }[82,105,106] \text {, polymor- } \\
\text { phism of paraoxonase I gene [107], polymorphisms for adrenergic and serotoninergic } \\
\text { receptors [108,109], angiotensin-converting enzyme [110], and inflammatory cytokines } \\
{[111,112] \text { have been reported. }} \\
\text { In Japan, NADH/NADPH oxidase p22 phox gene is a susceptibility locus in men, while } \\
\text { stromelysin-1 and interleukin-6 genes are susceptibility loci in women [113]. }\end{array}$ & $\begin{array}{l}\text { Studies of genetic mutations or polymorphisms in the } \\
\text { pathogenesis of CAS have been inconsistent [104]. } \\
\text { NO gene polymorphisms are found in only one-third of } \\
\text { the patients [27]. } \\
\text { Family history is not a risk factor for CAS [114]. }\end{array}$ \\
\hline
\end{tabular}

CAS, coronary artery spasm; hs-CRP, high-sensitivity C-reactive protein; NO, nitric oxide. 


\section{Autonomic nervous system}

It is known that the activity of the parasympathetic nervous system is enhanced at rest and is suppressed by physical activity [63]. The relationship between the autonomic nervous system and CAS is complex; however, both an increase in parasympathetic and sympathetic tone appear to be able to induce CAS. CAS often occurs during the night when vagal tone is higher [65]. In addition, acetylcholine is known to induce CAS [66], suggesting a role for vagal activity as a trigger of CAS. However, it has been shown that spontaneous ischemic episodes of CAS are often preceded by a reduction, rather than by an increase, of vagal activity [67], and followed by an increase in coronary levels of catecholamines [68]. Studies have also shown that CAS at night more frequently occurs during the rapid eye movement phases of sleep, when a reduction in vagal activity is associated with an increase in adrenergic activity [29,69], suggesting that CAS is not necessarily induced by vagal activity.

Although clinical studies have shown that CAS can be induced by catecholamines [63] or other sympathetic related stimuli $[70,71]$, a-blockade has been shown to be ineffective in controlling CAS symptoms [68]. In Japanese patients with acute myocardial infarction, atenolol does not promote coronary vasoreactivity to ergonovine [72], which can be explained by its selective $\beta-1$ adrenoceptor (chronotropic response) blocker effect without intrinsic sympathomimetic activity [73]. However, propranolol has been reported to promote CAS [74] presumably because of its non-selective $\beta$ adrenoceptor blocking effect [75]. Thus, the effects of $\beta$-blockers on cardiovascular behavior may differ depending upon their individual pharmacological modes of action.

\section{Inflammation}

Cigarette smoking, a major risk factor for CAS, is associated with low-grade inflammation [76]. In 1978, Lewis et al. [77] reported a patient who died of cardiogenic shock due to variant angina and localized pericarditis, suggesting for the first time a link between inflammation and CAS. In the mid 2000s, chronic inflammation was shown to be associated with CAS, as evidenced by elevated peripheral white blood cell and monocyte counts, hs-CRP, interleukin-6, and adhesion molecules [16,51]. Rho-kinase activity in peripheral leukocyte independently predicts the presence and severity of CAS, and correlates with plasma interleukin-6 level [78]. Shimokawa et al. [79] developed a porcine model of CAS by applying inflammatory cytokine interleukin- $1 \beta$ to the coronary artery. Furthermore, infiltration of inflammatory cells such as mast cells has been reported to be found at the site, or in the adventitia or plaque of coronary arteries in patients with CAS $[80,81]$. These findings suggest that there is increased inflammation in patients with CAS.

\section{Endothelial dysfunction}

Acetylcholine, ergonovine, serotonin, and histamine cause endothelium-dependent vasodilation by inducing nitric oxide (NO) release from the normal endothelium, and in the presence of endothelial dysfunction, they can induce CAS [27]. Dysfunctional endothelial NO synthase, and therefore deficient release of NO, have been shown to be strongly associated with CAS $[82,83]$. Previous reports using treatments with vitamin $\mathrm{E}$ or statins to improve endothelial function showed a decrease in symptoms of CAS $[84,85]$. Furthermore, NO deficiency has been demonstrated in the nonspastic coronary arteries as well as in the peripheral arteries, suggesting that $\mathrm{NO}$ deficiency may occur in the entire vascular system in patients with CAS [86]. However, endothelial dysfunction is not always present in patients with CAS $[87,88]$. Therefore, although endothelial cell dysfunction might favor the induction of CAS, other factors may also be involved in the pathogenesis of CAS.

\section{Smooth muscle cell hypercontractility}

Vascular smooth muscle cell relaxation and contraction are regulated mainly through myosin light chain dephosphorylation and phosphorylation, respectively. Increased smooth muscle cell Rho-kinase activity favors contraction by directly increasing sensitization to $\mathrm{Ca}^{2+}$ of myosin light chain and indirectly augmentating myosin light chain phosphorylation [89]. Shimokawa et al. showed that Rho-kinase activity is enhanced in coronary artery smooth muscle cell after wrapping the coronary artery with interleukin-1 $\beta$ beads in a porcine model of CAS [89-91]. They also showed that a Rho-kinase inhibitor, hydroxyfasudil, was able to prevent CAS in both the porcine model and in humans [92,93]. Other experimental models of spontaneous CAS have been developed in $\mathrm{K}_{\text {ATP }}$ mutant or SUR2 $\mathrm{K}_{\text {ATP }}$ knockout mice, suggesting that loss of function of $\mathrm{K}_{\mathrm{ATP}}$ channels causes smooth muscle cell hypercontraction in the absence of atherosclerotic lesions $[94,95]$. Mice deficient in $\mathrm{a}_{1 \mathrm{H}} \mathrm{T}$-type calcium channels demonstrate normal coronary artery contraction, but reduced relaxation in response to acetylcholine [96]. Together, these models show that vascular smooth muscle cell hyperreactivity can cause CAS through different pathways; however, their relevance to CAS in humans remains to be elucidated.

\section{Oxidative stress}

Smoking suppresses acetylcholine-induced endothelium-dependent relaxation, which is improved 
by antioxidants, such as vitamin C [97-100], suggesting NO could be degraded by oxygen free radicals. Oxygen-reactive species have a detrimental effect on the vessel wall, leading to inflammation, endothelial damage [99] and the constrictor response of vascular smooth muscle cells [101]. In CAS, a pathogenetic role for oxidative stress has been suggested by the presence of low plasma levels of vitamin E [102] and high plasma levels of thioredoxin [103]. However, while oxidative stress may predispose patients to CAS, there are debates over its effects on endothelial dysfunction as it has been reported that there is no endothelial NO deficiency or dysfunction in some patients with CAS [104].

\section{Genetics}

Studies of genetic mutations or polymorphisms in the pathogenesis of CAS have been inconsistent [105]. Mutations or polymorphisms of the endothelial NO synthase gene $[82,106,107]$ and polymorphisms of paraoxonase I gene [108] have been demonstrated to be significantly associated with CAS. However, NO gene polymorphisms are found in only one-third of patients [27]. Polymorphisms in genes coding for other proteins that have been described in CAS include adrenergic and serotoninergic receptors $[109,110]$, angiotensin-converting enzyme [111], and inflammatory cytokines [112,113]. In a Japanese cohort study, the NADH/NADPH oxidase p22 phox gene is a susceptibility locus in men, while stromelysin- 1 and interleukin- 6 genes are susceptibility loci in women [114]. However, family history is not a risk factor for CAS. Furthermore, CAS activity has fluctuations, with circadian variations in the short term and active and inactive phases in the long term [115]. Thus, gene-environment interactions may exist in the development of CAS [114].

\section{Diagnosis}

A diagnosis of CAS cannot be directly established based on symptoms [15], standard 12-lead electrocardiography results [30], ambulatory monitoring of electrocardiography [27], or exercise testing [116]. CAS may present with or without symptoms [20], and can exhibit either normal electrocardiographic findings at the beginning of an attack or when the attack is mild [27], or ST-segment elevation or depression during the attack [30]. With ambulatory monitoring of electrocardiography, the attack may not appear during the monitoring period [27]. If an exercise test reveals the appearance of ST-segment elevation or depression of $\geq 0.1 \mathrm{mV}$ in at least 2 contiguous leads, or negative $U$ waves which are not observed at rest, the patient may have CAS [9]. However, exercise testing results are usually negative in CAS [116].
Coronary angiography with provocative testing is the only certain method of diagnosing CAS [117]. In patients with ST-segment elevation during episodes of chest pain and a normal coronary angiography, provocative testing usually is not necessary for diagnosis of CAS [117]. Provoked CAS is defined as a reduction of $>50 \%$ [117], $>70 \%$ [118], $>75 \%$ [119], or $>90 \%$ [9] in luminal diameter with accompanying symptoms and/or ischemic ST-segment changes compared with postintracoronary nitroglycerin. Yasue et al. [27] suggested no limits on the reduction in luminal diameter required to diagnose CAS since myocardial ischemia must accompany the changes of vessel size. Although there are different diagnostic criteria in vessel diameter reduction, the angina and/or ischemic electrocardiographic changes during provocative testing are necessary to define the positive result.

Ergonovine and acetylcholine are the most commonly used agents for provocative testing [117]. While 2 forms of ergonovine are used in the angiographic laboratory, only methylergonovine is currently available in the United States [120]. Methylergonovine and acetylcholine cause smooth muscle cell contraction in the setting of endothelial dysfunction [121-124]. In early studies using intravenous provocative testing, patients received very high doses of ergonovine, leading to severe angina and deaths, thus causing the intravenous test to be abandoned $[120,125,126]$. It was later demonstrated that intracoronary ergonovine may be safer than intravenous administration to induce CAS [127]. To ensure a valid provocative testing, vasodilators (calcium antagonists and nitrates) must be withdrawn for $\geq 48$ hours except for sublingual nitroglycerin if necessary $[9,45,117]$. Moreover, the nitroglycerin solution must be well prepared before starting provocative testing to abolish documented CAS immediately through intracoronary administration. Atropine also suppresses acetylcholine-induced CAS [63]. The intracoronary rather than intravenous administration of methylergonovine is preferable in hypertensive patients and affords the opportunity to evaluate the left and right coronary arteries separately with small dosing increments of 5 to $10 \mu \mathrm{g}$ and a total dose not to exceed $50 \mu \mathrm{g}$ [117]. The effectiveness of intracoronary administration of acetylcholine in doses of 10 to $100 \mu \mathrm{g}$ is comparable to methylergonovine $[61,117,128]$. While a false negative test may be obtained when the disease activity is low, a negative test cannot always exclude CAS [124]. Of note, spontaneous CAS is diagnosed as the relief of obstructive stenosis after intracoronary nitroglycerin administration, emphasizing the importance of intracoronary nitroglycerin administration before attempted coronary intervention. Although other 
provocation tests have been proposed, such as histamine, epinephrine, dopamine, dobutamine [27], the cold pressor test [71], atrial pacing [7], and exercise [129], the intracoronary administration of methylergonovine is the most sensitive and specific method, and remains safe for CAS diagnosis, as long as procedural safeguards are adhered to.

In patients with $\geq 1$ episodes of CAS per day, the hyperventilation provocative test is nearly as effective as the methylergonovine provocative test [130]. It is, however, less sensitive in patients with less frequent attacks [117]. Furthermore, there is a danger of inducing simultaneous multi-vessel CAS with this method [27].

The complications of intracoronary provocative testing include angina, various arrhythmias, hypotension, dyspnea, flushing, nausea and vomiting $[27,131]$. There have been no reports of provocation-related mortality or myocardial infarction after the introduction of intracoronary provocative testing $[13,124]$. Furthermore, systemic effects, such as hypertension, are avoided [132]. Because ventricular fibrillation is a possible complication following intracoronary methylergonovine administration, its use outside the cardiac catheterization laboratory is not recommended. The absolute contraindications to methylergonovine included pregnancy, severe hypertension, severe left ventricular dysfunction, moderate to severe aortic stenosis and high-grade left main coronary artery disease [117].

\section{Treatment}

There is no specific cure. Any factor that may precipitate CAS, especially smoking, must be avoided. For medical treatment, calcium antagonists play a central role in the management of CAS. Of them, long-acting calcium antagonists are suggested to be given at night when attacks of CAS are frequent [27]. A high-dose long-acting calcium antagonist (e.g. nifedipine $80 \mathrm{mg} /$ day, amlodipine $20 \mathrm{mg} /$ day, diltiazem $360 \mathrm{mg}$ /day, or verapamil $480 \mathrm{mg} /$ day) has been suggested as the initial treatment and should be individually titrated to a dose that achieves adequate symptomatic response and avoid adverse effects [133], such as reductions in blood pressure and heart rate. The combination of 2 calcium antagonists (dihydropyridine and non-dihydropyridine) may be required for more severe symptoms. Furthermore, ischemic ST-segment depression can be reversed by treatment with calcium antagonists (Figure 1) [47]. Long-acting nitrates are effective in preventing a CAS recurrent attack; however, nitrate tolerance may limit their use as a first-line approach $[27,134]$. Nicorandil, a nitrate and K-channel activator, also suppresses CAS attacks [135]. Recent studies show that magne- sium, antioxidants, rho-kinase inhibitor fasudil, and fluvastatin [83] may have beneficial effects on CAS [27]. $\beta$-blockers, especially those with nonselective adrenoceptor blocking effects, may aggravate CAS [73], and therefore, should be avoided.

Drug-refractory CAS, defined as CAS not responding to treatment with 2 calcium antagonists plus a long-acting nitrate, is noted in approximately $20 \%$ of patients with CAS $[114,133]$. For those patients, while experience with percutaneous balloon angioplasty has been disappointing [136] and coronary artery bypass surgery has met with limited success [137], coronary stenting may represent an alternative treatment. Gaspardone et al. [138] reported that coronary stenting was effective in controlling symptoms at 6-month follow-up in 6 of 9 patients with drug-refractory CAS (up to $960 \mathrm{mg}$ diltiazem or $100 \mathrm{mg}$ nifedipine and nitrates). Other reports of coronary stenting in the management of drug-refractory CAS, however, did not use the combination and maximal doses of 2 calcium antagonists as aggressive medical treatment [139-141]. Although coronary stenting is thought to be effective in suppressing CAS, the use of calcium antagonists after stenting in previous reports indicates that CAS may develop at locations different from the previous stenting site. Collectively, these observations suggest that coronary stenting in combination with adequate medical treatment should be considered only in CAS patients who have significant coronary stenosis, accompanied with myocardial ischemia $[9,132,134,142]$. Because information on late clinical outcome after stenting is limited [138-141], it is unclear whether coronary stenting is useful to prevent anginal attacks in drug-refractory CAS patients without coronary stenosis $[9,132,142]$. Therefore, a randomized controlled trial should be done before coronary stenting can be recommended for drug-refractory CAS [143]. Finally, as stented coronary arteries show time-dependent loss of endothelial-dependent and -independent vasomotor function [144], CAS should be excluded before performing coronary stenting $[27,138,145]$.

The role implantable cardioverter defibrillators play in the management of patients with CAS-associated ventricular tachycardia or VF remains unclear. The use of an implantable cardioverter defibrillator with aggressive medical treatment has been reported to be effective in CAS patients who are survivors of cardiac arrest [146], or have associated ventricular fibrillation [147]. Further research is needed to investigate this issue.

\section{Prognosis}

Long-term survival is usually good as long as patients are on calcium antagonists and avoid smok- 
ing [148]. While the incidence of cardiac death among patients with CAS ranges from 0 to $10 \%$, depending on the duration of follow-up $[149,150]$, recurrent episodes of angina are frequently observed in 3.9 to $18.6 \%$ of patients $[45,149,151]$. The prognosis of CAS among Japanese patients is better than that among western patients $[148,152]$, which is probably due to the fact that the percentages of patients having multivessel CAS or impaired left ventricular function, or both, are smaller, and the percentage of patients receiving a calcium antagonist (diltiazem or nifedipine) as the initial treatment is higher in Japanese patients than in Western patients [148]. While age and left ventricular ejection fraction have been identified as predictors of adverse prognosis in CAS patients presenting with acute coronary syndrome [151], the highest hs-CRP tertile ( $>3 \mathrm{mg} / \mathrm{L})$ predicts higher risk of death, nonfatal myocardial infarction, and recurrent angina pectoris requiring repeat coronary angiography in all CAS patients without obstructive coronary artery disease [45]. The Japanese Coronary Spasm Association risk score, a recently developed scoring system for predicting adverse cardiac events in CAS patients presenting with angina, consists of 7 predictive factors, including smoking, resting angina alone, ST-segment elevation during angina, history of our-of-hospital cardiac arrest, organic stenosis, multivessel spasm, and $\beta$-blocker use [48]. Of note, this score has been suggested to be applied on the premise that CAS patients receive adequate medical treatment [48]. While the actual frequency of CAS attacks is difficult to assess because their occurrences tend to fluctuate, and are not necessarily accompanied by symptoms, treatments for CAS after diagnosis, which may be silent and lethal, should not be discontinued [153].

\section{Conclusions}

Current evidence suggests that CAS is a multifactorial disorder that cannot be explained by a single factor alone. Furthermore, since vascular smooth muscle cell hyperreactivity is nonspecific, the potential triggers of CAS may cause angina attacks in the same patient but under different conditions. Therefore, identification of CAS is important in daily clinical practice because of the differences in treatment strategies between obstructive coronary artery disease and CAS. To this end, adequate doses of intracoronary nitroglycerin administration before coronary interventions help differentiate spontaneous CAS from obstructive coronary artery disease, thus minimizing damage to vessels and preventing unnecessary procedures.

Abstinence from cigarette smoking and optimal dosing and timing of calcium antagonists remain the cornerstone of CAS therapy. Because recurrent episodes of angina are frequently observed in CAS, the need for further studies is paramount to help better define the molecular pathways responsible and develop more effective treatments for CAS.

\section{Abbreviations}

CAS: coronary artery spasm; hs-CRP: high-sensitivity C-reactive protein; NO: nitric oxide; VF: ventricular fibrillation.

\section{Competing Interests}

The authors have declared that no competing interest exists.

\section{References}

1. Maseri A, Parodi O, Severi S, Pesola A. Transient transmural reduction of myocardial blood flow demonstrated by thallium-201 scintigraphy, as a cause of variant angina. Circulation. 1976; 54: 280-288.

2. Prinzmetal M, Kennamer R, Merliss R, Wada T, Bor N. Angina pectoris. I. A variant form of angina pectoris; preliminary report. Am J Med. 1959; 27: 375-388.

3. Heberden W. Some account of a disorder of the breast. Medical Transactions. 1772; 2: 59-67.

4. MacAlpin RN, Kattus AA, Alvaro AB. Angina pectoris at rest with preservation of exercise capacity: Prinzmetal's variant angina. Circulation. 1973; 47: 946-958.

5. Sones FM Jr, Shirey EK. Cine coronary arteriography. Mod Concepts Cardiovasc Dis. 1962; 31: 735-738

6. Oliva PB, Potts DE, Pluss RG. Coronary arterial spasm in prinzmetal angina. Documentation by coronary arteriography. N Engl J Med. 1973; 288: 745-751.

7. Cheng TO, Bashour T, Kelser GA, Jr., Weiss L, Bacos J. Variant angina of prinzmetal with normal coronary arteriograms. A variant of the variant. Circulation. 1973; 47: 476-485

8. Maseri A, Mimmo R, Chierchia S, Marchesi C, Pesola A, L'Abbate A. Coronary artery spasm as a cause of acute myocardial ischemia in man. Chest. 1975; 68: 625-633.

9. JCS Joint Working Group. Japanese Circulation Society of Guidelines for Diagnosis and Treatment of Patients with Vasospastic Angina (Coronary Spastic Angina) (JCS 2008): digest version. Cir J. 2010; 74: 1745-1762.

10. Cheng CW, Yang NI, Lin KJ, Hung MJ, Cherng WJ. Role of coronary spasm for a positive noninvasive stress test result in angina pectoris patients without hemodynamically significant coronary artery disease. Am J Med Sci. 2008; 335: 354-362.

11. Nakagawa $\mathrm{H}$, Morikawa $Y$, Mizuno $Y$, et al. Coronary spasm preferentially occurs at branch points: an angiographic comparison with atherosclerotic plaque. Circ Cardiovasc Interv. 2009; 2: 97-104.

12. Beltrame JF, Sasayama S, Maseri A. Racial heterogeneity in coronary artery vasomotor reactivity: differences between Japanese and Caucasian patients. J Am Coll Cardiol. 1999; 33: 1442-1452.

13. Sueda S, Kohno H, Fukuda H, et al. Frequency of provoked coronary spasms in patients undergoing coronary arteriography using a spasm provocation test via intracoronary administration of ergonovine. Angiology. 2004; 55: 403-411.

14. Hung MY, Hsu KH, Hung MJ, Cheng CW, Cherng WJ. Interactions among gender, age, hypertension and C-reactive protein in coronary vasospasm. Eur J Clin Invest. 2010; 40: 1094-1103

15. Bertrand ME, LaBlanche JM, Tilmant PY, et al. Frequency of provoked coronary arterial spasm in 1089 consecutive patients undergoing coronary arteriography. Circulation. 1982; 65: 1299-1306.

16. Hung MJ, Cherng WJ, Cheng CW, Li LF. Comparison of serum levels of inflammatory markers in patients with coronary vasospasm without significant fixed coronary artery disease versus patients with stable angina pectoris and acute coronary syndromes with significant fixed coronary artery disease. Am J Cardiol. 2006; 97: 1429-1434.

17. Hung MJ, Cheng CW, Yang NI, Hung MY, Cherng WJ. Coronary vasospasm-induced acute coronary syndrome complicated by life-threatening cardiac arrhythmias in patients without hemodynamically significant coronary artery disease. Int J Cardiol. 2007; 117: 37-44.

18. Ong P, Athanasiadis A, Hill S, Vogelsberg H, Voehringer M, Sechtem U. Coronary artery spasm as a frequent cause of acute coronary syndrome: The CASPAR (Coronary Artery Spasm in Patients With Acute Coronary Syndrome) Study. J Am Coll Cardiol. 2008; 52: 523-527.

19. Maseri A, L'Abbate A, Baroldi G, et al. Coronary vasospasm as a possible cause of myocardial infarction. A conclusion derived from the study of "preinfarction" angina. N Engl J Med. 1978; 299: 1271-1277.

20. Yasue H, Kugiyama K. Coronary spasm: clinical features and pathogenesis. Intern Med. 1997; 36: 760-765.

21. Hung MJ, Hung MY, Cheng CW, Yang NI, Cherng WJ. Clinical characteristics of patients with exercise-induced ST-segment elevation without prior myocardial infarction. Circ J. 2006; 70: 254-261.

22. Nakamura M, Takeshita A, Nose $Y$. Clinical characteristics associated with myocardial infarction, arrhythmias, and sudden death in patients with vasospastic angina. Circulation. 1987; 75: 1110-1116.

23. Maseri A, Severi S, Nes MD, et al. "Variant" angina: one aspect of a continuous spectrum of vasospastic myocardial ischemia. Pathogenetic mechanisms, estimated 
incidence and clinical and coronary arteriographic findings in 138 patients. Am J Cardiol. 1978; 42: 1019-1035.

24. Hillis LD, Braunwald E. Coronary-artery spasm. N Engl J Med. 1978; 299: 695-702.

25. Araki H, Koiwaya Y, Nakagaki O, Nakamura M. Diurnal distribution of ST-segment elevation and related arrhythmias in patients with variant angina: a study by ambulatory ECG monitoring. Circulation. 1983; 67: 995-1000.

26. Yasue H, Omote S, Takizawa A, Nagao M. Coronary arterial spasm in ischemic heart disease and its pathogenesis. A review. Circ Res. 1983; 52: I147-152

27. Yasue H, Nakagawa H, Itoh T, Harada E, Mizuno Y. Coronary artery spasm--clinical features, diagnosis, pathogenesis, and treatment. J Cardiol. 2008; 51: 2-17.

28. Jougasaki M, Yasue H, Takahashi K. Perivascular nerve lesion of the coronary artery involved in spasm in a patient with variant angina. Pathology. 1989; 21: 304-307.

29. Otsuka K, Yanaga T, Watanabe H. Variant angina and REM sleep. Am Heart J. 1988; 115: 1343-1346.

30. Yasue H, Omote S, Takizawa A, et al. Comparison of coronary arteriographic findings during angina pectoris associated with S-T elevation or depression. Am J Cardiol. 1981; 47: 539-546.

31. Ozaki Y, Keane D, Serruys PW. Fluctuation of spastic location in patients with vasospastic angina: a quantitative angiographic study. J Am Coll Cardiol. 1995; 26: 1606-1614.

32. Waters DD, Szlachcic J, Theroux P, Dauwe F, Mizgala HF. Ergonovine testing to detect spontaneous remissions of variant angina during long-term treatment with calcium antagonist drugs. Am J Cardiol. 1981; 47: 179-184.

33. Whittle JL, Feldman RL, Pepine CJ, Curry RC, Conti CR. Variability of electrocardiographic responses to repeated ergonovine provocation in variant angina patients with coronary artery spasm. Am Heart J. 1982; 103: 161-167.

34. Seniuk W, Mularek-Kubzdela T, Grygier M, Grajek S, Cieśliński A. Cardiac arrest related to coronary spasm in patients with variant angina: a three-case study. J Intern Med. 2002; 252: 368-376

35. Hung MJ, Wang CH, Kuo LT, Cherng WJ. Coronary artery spasm-induced paroxysmal atrial fibrillation--a case report. Angiology. 2001; 52: 559-562.

36. Myerburg RJ, Kessler KM, Mallon SM, et al. Life-threatening ventricular arrhythmias in patients with silent myocardial ischemia due to coronary-artery spasm. N Engl J Med. 1992; 326: 1451-1455.

37. Maseri A, Severi S, Marzullo P. Role of coronary arterial spasm in sudden coronary ischemic death. Ann N Y Acad Sci. 1982; 382: 204-217.

38. Romagnoli E, Lanza GA. Acute myocardial infarction with normal coronary arteries: role of coronary artery spasm and arrhythmic complications. Int J Cardiol. 2007; 117: $3-5$

39. Olgin JE, Zipes DP. Specific arrhythmias: diagnosis and treatment. In: Zipes DP, Libby P, Bonow RO, Braunwald E, Eds. Heart Disease: A Textbook of Cardiovascular Medicine. $7^{\text {th }}$ ed. Philadelphia: Saunders, 2005; 853

40. Hung MY, Hung MJ, Cheng CW, Yang NI, Cherng WJ. Safety and predictors of a positive result of intracoronary ergonovine testing in patients with ischemic heart disease without hemodynamically significant coronary artery stenosis in Taiwan. Acta Cardiol Sin. 2007; 23: 150-159.

41. Choquette G, Wasserman F, Lisker S, Bellet S. Spontaneous reversion of ventricular fibrillation to normal sinus rhythm in a case of acute myocardial infarction. Am Heart J. 1956; 51: 455-459.

42. Patt MV, Podrid PJ, Friedman PL, Lown B. Spontaneous reversion of ventricular fibrillation. Am Heart J. 1988; 115: 919-923.

43. Dubner SJ, Gimeno GM, Elencwajg B, Leguizamón J, Trongé JE, Quinteiro R. Ventricular fibrillation with spontaneous reversion on ambulatory ECG in the absence of heart disease. Am Heart J. 1983; 105: 691-693.

44. Farmer DM, Swygman CA, Wang PJ, Mark Estes NA 3rd, Link MS. Evidence that nonsustained polymorphic ventricular tachycardia causes syncope (data from implantable cardioverter defibrillators). Am J Cardiol. 2003; 91: 606-609.

45. Hung MJ, Hsu KH, Hu WS, Chang NC, Hung MY. C-reactive protein for predicting prognosis and its gender-specific associations with diabetes mellitus and hypertension in the development of coronary artery spasm. PLoS One. 2013; 8: e77655.

46. Takaoka K, Yoshimura M, Ogawa H, et al. Comparison of the risk factors for coronary artery spasm with those for organic stenosis in a Japanese population: role of cigarette smoking. Int J Cardiol. 2000; 72: 121-126.

47. Hung MY, Hsu KH, Hung MJ, et al. Interaction between cigarette smoking and high-sensitivity C-reactive protein in the development of coronary vasospasm in patients without hemodynamically significant coronary artery disease. Am J Med Sci. 2009; 338: 440-446.

48. Sugiishi M, Takatsu F. Cigarette smoking is a major risk factor for coronary spasm. Circulation. 1993; 87: 76-79.

49. Takagi Y, Takahashi J, Yasuda S, et al; Japanese Coronary Spasm Association. Prognostic stratification of patients with vasospastic angina: a comprehensive clinical risk score developed by the Japanese Coronary Spasm Association. J Am Coll Cardiol. 2013; 62: 1144-1153

50. Pristipino C, Beltrame JF, Finocchiaro ML, et al. Major racial differences in coronary constrictor response between japanese and caucasians with recent myocardial infarction. Circulation. 2000; 101: 1102-1108

51. Itoh T, Mizuno Y, Harada E, Yoshimura M, Ogawa H, Yasue H. Coronary spasm is associated with chronic low-grade inflammation. Circ J. 2007; 71: 1074-1078.

52. Roeters van Lennep JE, Westerveld HT, Erkelens DW, van der Wall EE. Risk factors for coronary heart disease: implications of gender. Cardiovasc Res. 2002; 53: 538-549.

53. Yusuf S, Hawken S, Ounpuu S, et al; INTERHEART Study Investigators. Effect of potentially modifiable risk factors associated with myocardial infarction in 52 countries (the INTERHEART study): case-control study. Lancet. 2004; 364: 937-952.

54. Yeung AC, Vekshtein VI, Krantz DS, et al. The effect of atherosclerosis on the vasomotor response of coronary arteries to mental stress. N Engl J Med. 1991; 325: 1551-1556.

55. Teragawa H, Kato M, Yamagata T, Matsuura H, Kajiyama G. The preventive effect of magnesium on coronary spasm in patients with vasospastic angina. Chest. 2000; 118: $1690-1695$

56. Fernandez D, Rosenthal JE, Cohen LS, Hammond G, Wolfson S. Alcohol-induced Prinzmetal variant angina. Am J Cardiol. 1973; 32: 238-239.
57. Oi K, Shimokawa $\mathrm{H}$, Hiroki J, et al. Remnant lipoproteins from patients with sudden cardiac death enhance coronary vasospastic activity through upregulation of Rho-kinase. Arterioscler Thromb Vasc Biol. 2004; 24: 918-922.

58. Pitts WR, Lange RA, Cigarroa JE, Hillis LD. Cocaine-induced myocardial ischemia and infarction: pathophysiology, recognition, and management. Prog Cardiovasc Dis. 1997; 40: 65-76.

59. Hung MY, Hsu KH, Hu WS, Chang NC, Huang CY, Hung MJ. Gender-specific prognosis and risk impact of C-reactive protein, hemoglobin and platelet in the development of coronary spasm. Int J Med Sci. 2013; 10: 255-264.

60. Heupler FA Jr, Proudfit WL, Razavi M, Shirey EK, Greenstreet R, Sheldon WC. Ergonovine maleate provocative test for coronary arterial spasm. Am J Cardiol. 1978; 41: 631-640.

61. Tada M, Kuzuya T, Inoue M, et al. Elevation of thromboxane B2 levels in patients with classic and variant angina Pectoris. Circulation. 1981; 64: 1107-1115.

62. Kounis NG. Kounis syndrome (allergic angina and allergic myocardial infarction): a natural paradigm?. Int J Cardiol. 2006; 110: 7-14

63. Yasue $\mathrm{H}$, Horio $\mathrm{Y}$, Nakamura N, et al. Induction of coronary artery spasm by acetylcholine in patients with variant angina: possible role of the parasympathetic nervous system in the pathogenesis of coronary artery spasm. Circulation. 1986; 74: 955-963.

64. Kugiyama $\mathrm{K}$, Yasue $\mathrm{H}$, Horio $\mathrm{Y}$, Morikami $\mathrm{Y}$, Fujii H, Kimura T. Possible role of parasympathetic nervous system in the pathogenesis of exercise-induced coronary artery spasm. Am Heart J. 1986; 112: 605-606.

65. Waters DD, Miller DD, Bouchard A, Bosch X, Theroux P. Circadian variation in variant angina. Am J Cardiol. 1984; 54: 61-64.

66. Kaski JC, Maseri A, Vejar M, Crea F, Hackett D. Spontaneous coronary artery spasm in variant angina is caused by a local hyperreactivity to a generalized constrictor stimulus. J Am Coll Cardiol. 1989; 14: 1456-1463.

67. Lanza GA, Pedrotti P, Pasceri V, Lucente M, Crea F, Maseri A. Autonomic changes associated with spontaneous coronary spasm in patients with variant angina. J Am Coll Cardiol. 1996; 28: 1249-1256.

68. Robertson RM, Bernard Y, Robertson D. Arterial and coronary sinus catecholamines in the course of spontaneous coronary artery spasm. Am Heart J. 1983; 105: 901-906.

69. King MJ, Zir LM, Kaltman AJ, Fox AC. Variant angina associated with angiographically demonstrated coronary artery spasm and REM sleep. Am J Med Sci. 1973; 265: 419-422.

70. El Menyar AA. Drug-induced myocardial infarction secondary to coronary artery spasm in teenagers and young adults. J Postgrad Med. 2006; 52: 51-56.

71. Raizner AE, Chahine RA, Ishimori T, et al. Provocation of coronary artery spasm by the cold pressor test. Hemodynamic, arteriographic and quantitative angiographic observations. Circulation. 1980; 62: 925-932.

72. Shirotani M, Yokota R, Kouchi I, et al. Influence of atenolol on coronary artery spasm after acute myocardial infarction in a Japanese population. Int J Cardiol. 2010; 139: 181-186

73. Svendsen TL. Central hemodynamics of beta-adrenoceptor blocking drugs: beta 1 selectivity versus intrinsic sympathomimetic activity. J Cardiovasc Pharmacol. 1983; 5 (Suppl 1): S21-25.

74. Tilmant PY, Lablanche JM, Thieuleux FA, Dupuis BA, Bertrand ME. Detrimental effect of propranolol in patients with coronary arterial spasm countered by combination with diltiazem. Am J Cardiol. 1983; 52: 230-233.

75. Kazanietz MG, Enero MA. Desensitization of the beta-2 adrenoceptor-mediated vasodilation in rat aorta after prolonged treatment with the beta-2 adrenoceptor agonist clenbuterol. J Pharmacol Exp Ther. 1990; 252: 758-764.

76. Yasue H, Hirai N, Mizuno Y, et al. Low-grade inflammation, thrombogenicity, and atherogenic lipid profile in cigarette smokers. Circ J. 2006; 70: 8-13.

77. Lewis JR, Kisilevsky R, Armstrong PW. Prinzmetal's angina, normal coronary arteries and pericarditis. Can Med Assoc J. 1978; 119: 36-39.

78. Hung MJ, Cherng WJ, Hung MY, et al. Increased leukocyte Rho-associated coiled-coil containing protein kinase activity predicts the presence and severity of coronary vasospastic angina. Atherosclerosis. 2012; 221: 521-526.

79. Shimokawa H. Cellular and molecular mechanisms of coronary artery spasm: lessons from animal models. Jpn Circ J. 2000; 64: 1-12.

80. Forman MB, Oates JA, Robertson D, Robertson RM, Roberts LJ 2nd, Virmani R Increased adventitial mast cells in a patient with coronary spasm. N Engl J Med. 1985; 313: 1138-1141.

81. Kohchi K, Takebayashi S, Hiroki T, Nobuyoshi M. Significance of adventitial inflammation of the coronary artery in patients with unstable angina: results at autopsy. Circulation. 1985; 71: 709-716.

82. Kugiyama K, Yasue H, Okumura K, et al. Nitric oxide activity is deficient in spasm arteries of patients with coronary spastic angina. Circulation. 1996; 94: 266-271.

83. Nakayama M, Yasue H, Yoshimura M, et al. T-786-->C mutation in the 5'-flanking region of the endothelial nitric oxide synthase gene is associated with coronary spasm. Circulation. 1999; 99: 2864-2870.

84. Motoyama T, Kawano H, Kugiyama K, et al. Vitamin E administration improves impairment of endothelium-dependent vasodilation in patients with coronary spastic angina. J Am Coll Cardiol. 1998; 32: 1672-1679.

85. Yasue H, Mizuno Y, Harada E, et al; SCAST (Statin and Coronary Artery Spasm Trial) Investigators. Effects of a 3-hydroxy-3-methylglutaryl coenzyme A reductase inhibitor, fluvastatin, on coronary spasm after withdrawal of calcium-channel blockers. J Am Coll Cardiol. 2008; 51: 1742-1748.

86. Okumura K, Yasue H, Matsuyama K, et al. Diffuse disorder of coronary artery vasomotility in patients with coronary spastic angina. Hyperreactivity to the constrictor effects of acetylcholine and the dilator effects of nitroglycerin. J Am Coll Cardiol. 1996; 27: 45-52

87. Egashira K, Inou T, Yamada A, Hirooka Y, Takeshita A. Preserved endothelium-dependent vasodilation at the vasospastic site in patients with variant angina. J Clin Invest. 1992; 89: 1047-1052

88. Ito $\mathrm{K}$, Akita H, Kanazawa K, et al. Systemic endothelial function is preserved in men with both active and inactive variant angina pectoris. Am J Cardiol. 1999; 84: 1347-1349. 
89. Kandabashi $\mathrm{T}$, Shimokawa $\mathrm{H}$, Miyata $\mathrm{K}$, et al. Inhibition of myosin phosphatase by upregulated rho-kinase plays a key role for coronary artery spasm in a porcine model with interleukin-1beta. Circulation. 2000; 101: 1319-1323.

90. Shimokawa H, Tomoike H, Nabeyama S, Yamamoto H, Ishii Y, Tanaka K, Nakamura $\mathrm{M}$. Coronary artery spasm induced in miniature swine: angiographic evidence and relation to coronary atherosclerosis. Am Heart J. 1985; 110: 300-310.

91. Kandabashi T, Shimokawa $\mathrm{H}$, Miyata $\mathrm{K}$, et al. Evidence for protein kinase C-mediated activation of Rho-kinase in a porcine model of coronary artery spasm. Arterioscler Thromb Vasc Biol. 2003; 23: 2209-2214.

92. Shimokawa $\mathrm{H}$, Seto $\mathrm{M}$, Katsumata $\mathrm{N}$, et al. Rho-kinase-mediated pathway induces enhanced myosin light chain phosphorylations in a swine model of coronary artery spasm. Cardiovasc Res. 1999; 43: 1029-1039.

93. Masumoto A, Mohri M, Shimokawa H, Urakami L, Usui M, Takeshita A. Suppression of coronary artery spasm by the Rho-kinase inhibitor fasudil in patients with vasospastic angina. Circulation. 2002; 105: 1545-1547.

94. Chutkow WA, Pu J, Wheeler MT, et al. Episodic coronary artery vasospasm and hypertension develop in the absence of Sur2 K(ATP) channels. J Clin Invest. 2002; 110: 203-208.

95. Kakkar R, Ye B, Stoller DA, et al. Spontaneous coronary vasospasm in KATP mutant mice arises from a smooth muscle-extrinsic process. Circ Res. 2006; 98: 682-689.

96. Chen CC, Lamping KG, Nuno DW, et al. Abnormal coronary function in mice deficient in alpha1H T-type Ca2+ channels. Science. 2003; 302: 1416-1418.

97. Ota Y, Kugiyama K, Sugiyama S, et al. Impairment of endothelium-dependent relaxation of rabbit aortas by cigarette smoke extract--role of free radicals and attenuation by captopril. Atherosclerosis. 1997; 131: 195-202.

98. Sugiyama S, Kugiyama K, Ohgushi M, et al. Supersensitivity of atherosclerotic artery to constrictor effect of cigarette smoke extract. Cardiovasc Res. 1998; 38: 508-515.

99. Kugiyama K, Yasue H, Ohgushi M, et al. Deficiency in nitric oxide bioactivity in epicardial coronary arteries of cigarette smokers. J Am Coll Cardiol. 1996; 28: 1161-1167.

100. Motoyama T, Kawano H, Kugiyama K, et al. Endothelium-dependent vasodilation in the brachial artery is impaired in smokers: effect of vitamin C. Am J Physiol. 1997; 273(4 Pt 2): H1644-650.

101. Rodrigo R, González J, Paoletto F. The role of oxidative stress in the pathophysiology of hypertension. Hypertens Res. 2011; 34: 431-440.

102. Miwa K, Miyagi $Y$, Igawa A, Nakagawa $K$, Inoue $H$. Vitamin $E$ deficiency in variant angina. Circulation. 1996; 94: 14-18.

103. Miyamoto S, Kawano H, Sakamoto T, et al. Increased plasma levels of thioredoxin in patients with coronary spastic angina. Antioxid Redox Signal. 2004; 6: 75-80.

104. Egashira K, Katsuda Y, Mohri M, et al. Basal release of endothelium-derived nitric oxide at site of spasm in patients with variant angina. J Am Coll Cardiol. 1996; 27: 1444-1449.

105. Miwa K, Fujita M, Sasayama S. Recent insights into the mechanisms, predisposing factors, and racial differences of coronary vasospasm. Heart Vessels. 2005; 20: 1-7.

106. Yoshimura M, Yasue H, Nakayama M, et al. A missense Glu298Asp variant in the endothelial nitric oxide synthase gene is associated with coronary spasm in the Japanese. Hum Genet. 1998; 103: 65-69.

107. Kaneda H, Taguchi J, Kuwada $Y$, et al. Coronary artery spasm and the polymorphisms of the endothelial nitric oxide synthase gene. Circ J. 2006; 70: 409-413.

108. Ito T, Yasue H, Yoshimura M, et al. Paraoxonase gene Gln192Arg (Q192R) polymorphism is associated with coronary artery spasm. Hum Genet. 2002; 110: 89-94.

109. Park JS, Zhang SY, Jo SH, et al. Common adrenergic receptor polymorphisms as novel risk factors for vasospastic angina. Am Heart J. 2006; 151: 864-869.

110. Kaumann AJ, Levy FO. 5-hydroxytryptamine receptors in the human cardiovascular system. Pharmacol Ther. 2006; 111: 674-706.

111. Oike Y, Hata A, Ogata Y, Numata Y, Shido K, Kondo K. Angiotensin converting enzyme as a genetic risk factor for coronary artery spasm. Implication in the pathogenesis of myocardial infarction. J Clin Invest. 1995; 96: 2975-2979.

112. Inoue N, Kawashima S, Kanazawa K, Yamada S, Akita H, Yokoyama M. Polymorphism of the NADH/NADPH oxidase p22 phox gene in patients with coronary artery disease. Circulation. 1998; 97: 135-137.

113. Nakano T, Osanai T, Tomita H, Sekimata M, Homma Y, Okumura K. Enhanced activity of variant phospholipase C-delta1 protein $(\mathrm{R} 257 \mathrm{H})$ detected in patients with coronary artery spasm. Circulation. 2002; 105: 2024-2029.

114. Murase Y, Yamada Y, Hirashiki A, et al. Genetic risk and gene-environment interaction in coronary artery spasm in Japanese men and women. Eur Heart J. 2004; 25: 970-977.

115. Lanza GA, Careri G, Crea F. Mechanisms of coronary artery spasm. Circulation. 2011; 124: 1774-1782.

116. Cheng TO. Ergonovine test for coronary artery spasm. Int J Cardiol. 2007; 114: 249-250.

117. Scanlon PJ, Faxon DP, Audet AM, et al. ACC/AHA guidelines for coronary angiography. A report of the American College of Cardiology/American Heart Association Task Force on practice guidelines (Committee on Coronary Angiography). Developed in collaboration with the Society for Cardiac Angiography and Interventions. J Am Coll Cardiol. 1999; 33: 1756-1824.

118. Baim DS. Coronary angiography. In: Baim DS, eds. Grossman's cardiac catheterization, angiography, and intervention. 7th ed. Philadelphia: Lippincott Williams \& Wilkins; 2006: 215.

119. Bertrand ME, Lablanche JM, Tilmant PY, Thieuleux FA, Delforge MG, Chahine RA. The provocation of coronary arterial spasm in patients with recent transmural myocardial infarction. Eur Heart J. 1983; 4: 532-535.

120. Hamilton KK, Pepine CJ. A renaissance of provocative testing for coronary spasm? J Am Coll Cardiol. 2000; 35: 1857-1859.

121. Martin W, Villani GM, Jothianandan D, Furchgott RF. Selective blockade of endothelium-dependent and glyceryl trinitrate-induced relaxation by hemoglobin and by methylene blue in the rabbit aorta. J Pharmacol Exp Ther. 1985; 232: 708-716.

122. Shimokawa H, Flavahan NA, Shepherd JT, Vanhoutte PM. Endothelium-dependent inhibition of ergonovine-induced contraction is impaired in porcine coronary arteries with regenerated endothelium. Circulation. 1989; 80: 643-650.

123. Furchgott RF, Zawadzki JV. The obligatory role of endothelial cells in the relaxation of arterial smooth muscle by acetylcholine. Nature. 1980; 288 : 373-376.
124. Zaya M, Mehta PK, Bairey Merz CN. Provocative Testing for Coronary Reactivity and Spasm. J Am Coll Cardiol. 2014; 63: 103-109.

125. Buxton A, Goldberg S, Hirshfeld JW, et al. Refractory ergonovine-induced coronary vasospasm: importance of intracoronary nitroglycerin. Am J Cardiol. 1980; 46: 329-334.

126. Harding MB, Leithe ME, Mark DB, et al. Ergonovine maleate testing during cardiac catheterization: a 10-year perspective in 3,447 patients without significant coronary artery disease or Prinzmetal's variant angina. J Am Coll Cardiol. 1992; 20: 107-111.

127. Hackett D, Larkin S, Chierchia S, Davies G, Kaski JC, Maseri A. Induction of coronary artery spasm by a direct local action of ergonovine. Circulation. 1987; 75: 577-582.

128. Okumura K, Yasue H, Horio $\mathrm{Y}$, et al. Multivessel coronary spasm in patients with variant angina: a study with intracoronary injection of acetylcholine. Circulation. 1988; 77: 535-542

129. Cheng TO. Coronary artery spasm--1984. Chest. 1984; 86: 918-926.

130. Previtali M, Ardissino D, Barberis P, Panciroli C, Chimienti M, Salerno JA. Hyperventilation and ergonovine tests in Prinzmetal's variant angina pectoris in men. Am J Cardiol. 1989; 63: 17-20.

131. Eshaghpour E, Mattioli L, Williams ML, Moghadam AN. Acetylcholine in the treatment of idiopathic respiratory distress syndrome. J Pediatr. 1967; 71: 243-246.

132. Fournier JA, Cortacero JA, Turá A, Hernández-Aparicio C, Granado C, Vallejo J. Effects of intracoronary injection of ergonovine on angiographic normal coronary arteries: study of 108 consecutive patients. Clin Cardiol. 1989; 12: 561-568.

133. de Lemons JA, O'Rourke RA. Unstable angina and non-ST-segment elevation myocardial infarction. In: Fuster V, Eds. Hurst's The Heart. 12th ed. New York: McGraw-Hill; 2008: 1371-1372.

134. [Internet] Pinto DS, Beltrame JF, Crea F. Variant angina. http://www.uptodate.com/contents/variant-angina?source=search_result\&search $=$ variant+angina\&selectedTitle=1\%7E103.

135. Kaski JC. Management of vasospastic angina--role of nicorandil. Cardiovasc Drugs Ther. 1995; 9 (Suppl 2): 221-227.

136. Bertrand ME, LaBlanche JM, Thieuleux FA, Fourrier JL, Traisnel G, Asseman P. Comparative results of percutaneous transluminal coronary angioplasty in patients with dynamic versus fixed coronary stenosis. J Am Coll Cardiol 1986; 8: 504-508.

137. Bertrand ME, Lablanche JM, Rousseau MF, Warembourg HH Jr, Stankowtak C, Soots G. Surgical treatment of variant angina: use of plexectomy with aortocoronary bypass. Circulation 1980; 61: 877-882.

138. Gaspardone A, Tomai F, Versaci F, et al. Coronary artery stent placement in patients with variant angina refractory to medical treatment. Am J Cardiol. 1999; 84: 96-98.

139. Chou HH, Lim KE, Ko YL. Treatment of spontaneous left main coronary artery spasm with a drug-eluting stent. Acta Cardiol Sin. 2009; 25: 43-46.

140. Chou MT, Huang TY. Coronary stenting for coronary vasospasm complicated with refractory ventricular tachycardia and fibrillation. Acta Cardiol Sin. 2012; 28: 145-147.

141. Nakamura T, Furukawa K, Uchiyama H, Seo Y, Okuda S, Ebizawa T. Stent placement for recurrent vasospastic angina resistant to medical treatment. Cathet Cardiovasc Diagn 1997; 42: 440-443.

142. Cannon CP, Braunwald E. Unstable angina and non-ST elevation myocardial infarction. In: Libby P, Eds. Braunwald's Heart Disease: A Textbook of Cardiovascular Medicine. $8^{\text {th }}$ ed. Philadelphia: Saunders, 2008: 1339.

143. Cheng TO. Percutaneous coronary intervention for variant angina: balloon vs. stent. Catheter Cardiovasc Interv. 2002; 56: 21.

144. Plass CA, Sabdyusheva-Litschauer I, Bernhart A, et al. Time course of endothelium-dependent and -independent coronary vasomotor response to coronary balloons and stents: comparison of plain and drug-eluting balloons and stents. J Am Coll Cardiol Intv. 2012; 5: 741-751.

145. Yuksel UC, Celik T, Iyisoy A, Kursaklioglu H, Amasyali B, Kose S. Polymorphic ventricular tachycardia induced by coronary vasospasm: a malignant case of variant angina. Int J Cardiol. 2007; 121: 210-212.

146. Chevalier P, Dacosta A, Defaye P, et al. Arrhythmic cardiac arrest due to isolated coronary artery spasm: long-term outcome of seven resuscitated patients. J Am Coll Cardiol. 1998; 31: 57-61.

147. Meisel SR, Mazur A, Chetboun I, et al. Usefulness of implantable cardioverter-defibrillators in refractory variant angina pectoris complicated by ventricular fibrillation in patients with angiographically normal coronary arteries. Am J Cardiol. 2002; 89: 1114-1116.

148. Yasue $\mathrm{H}$, Takizawa A, Nagao M, et al. Long-term prognosis for patients with variant angina and influential factors. Circulation. 1988; 78: 1-9.

149. Bory M, Pierron F, Panagides D, Bonnet JL, Yvorra S, Desfossez L. Coronary artery spasm in patients with normal or near normal coronary arteries. Long-term follow-up of 277 patients. Eur Heart J. 1996; 17: 1015-1021.

150. Freedman SB, Richmond DR, Alwyn M, Kelly DT. Late follow-up (41 to 102 months) of medically treated patients with coronary artery spasm and minor atherosclerotic coronary obstructions. Am J Cardiol. 1986; 57: 1261-1263.

151. Ong $P$, Athanasiadis A, Borgulya $G$, Voehringer $M$, Sechtem U.3-year follow-up of patients with coronary artery spasm as cause of acute coronary syndrome: the CASPAR (coronary artery spasm in patients with acute coronary syndrome) study follow-up. J Am Coll Cardiol. 2011; 57: 147-152.

152. Walling A, Waters DD, Miller DD, Roy D, Pelletier GB, Théroux P. Long-term prognosis of patients with variant angina. Circulation. 1987; 76: 990-997.

153. Ueda O, Kohchi K, Kishi $Y$, Numano F. Long lasting spasticity in controlled vasospastic angina. Heart. 1999; 81: 528-532. 